\title{
Türkiye'de Hemşirelik Lisans Programlarında Hemşirelik Tarihi Dersi Öğretiminin Incelenmesi ${ }^{*}$
}

\author{
Investigation of Teaching of Nursing History Course in Nursing Undergraduate Programs in Turkey \\ Serap Torun
}

'Dr. Öğr. Üyesi, Çukurova Üniversitesi Sağlık Bilimleri Fakültesi Hemşirelik Bölümü, Hemşirelikte Yönetim AD. https://orcid.org/0000-0002-1651-2735

\section{öz}

Bu çalışma Türkiye'de Hemşirelik Lisans düzeyinde eğitim veren yükseköğrenim kurumlarında Hemşirelik Tarihi dersinin öğretimine ilişkin durumu belirlemek amacıyla yapılmıştır. 2018 yılı Yükseköğretim Kurumu istatistiklerinden yararlanılarak aktif olarak eğitim veren hemşirelik lisans programları belirlenmiştir. Hemşirelik lisans programlarının internet sayfalarından Hemşirelik Tarihi Dersine ilişkin bilgiler toplanmıştır. Ders adı, saati, yarıyılı, ders içeriği, dersi veren öğretim elemanı ve öğretim elemanın branşı ana değerlendirme konularını oluşturmuştur. Hemşirelik Lisans eğitimi veren tüm kurumların 59 unda Hemşirelik Tarihi'nin ders adı değişmekle birlikte olarak müfredatta yer aldığı görülmüştür. Devlet ve Vakıf Üniversitelerinde 2018 yılında aktif 83 adet Sağıı Bilimleri Fakültesi Hemşirelik Bölümü bulunduğu, hemşirelik tarihine ilişkin dersin adı, içeriği ve konuları açısından farkılıklar bulunduğu gibi dersin hiç verilmediği bölümlerinde olduğu saptanmıştır. 15 Hemşirelik Fakültesinin sadece dördünde hemşirelik tarihi içerikli ders bulunduğu belirlenmiştir. Öğretim elemanlarının ünvanı ve anabilim dalı aidiyeti çeşitlilik göstermekle birlikte dersin içeriğinin öğretim elemanın ilgi alanına ve branşına göre değiştiğini söylemek olanaklıdır.

Hemşirelik lisans eğitiminde mesleki aidiyet bilincinin ve hemşirelik felsefesinin öğrenim hayatında gelişebilmesi için önem arz eden Hemşirelik Tarihi dersinde standart bir müfredat oluşturma yoluna gidilmesi önerilebilir.

Anahtar Kelimeler: Hemşirelik tarihi, ders, eğitim

\section{ABSTRACT}

This study has been conducted to identify the status of the teaching of Nursing History course in the higher education institutions which provide Nursing education at an undergraduate level in Turkey. The study has identified the nursing undergraduate programs which actively provide education by utilizing the 2018 statistics from the Council of Higher Education. Information on Nursing History course on the internet pages of the Nursing undergraduate programs have been collected. The main evaluation subjects consist of the course title, hour, semester, course content, lecturer, and his/her branch. In 59 of all institutions providing undergraduate education in Nursing, it has been observed that while the course name of the Nursing History changes, it is included in the curriculum. It has been observed that there are 83 active Departments of Nursing, Faculty of Health Sciences in State and Foundation Universities in 2018, and as the course name, content and subjects may change, there are some departments that do not include the Nursing History at all. It was identified that only four of the 15 Faculty of Nursing had courses in nursing history. It is possible to say that the content of the course varies according to the area of interest and branch of the lecturer while the title and department affiliation of the lecturers change.

It may be suggested to create a standard curriculum in the Nursing History course which is of high importance for developing the professional sense of belonging and philosophy of nursing in the education life during the nursing undergraduate education.

Keywords: Nursing history, course, education

*Lokman Hekim Dergisi, 2019; 9 (3): 317-325

DOI: $10.31020 /$ mutftd.587749

e-ISSN: $1309-8004$

Geliş Tarihi - Received: 5 Temmuz 2019; Kabul Tarihi - Accepted: 19 Ağustos 2019

iletişim - Correspondence Author: Serap Torun < torunserap@gmail.com> 


\section{Giriş}

Tarih; Toplumları, milletleri, kuruluşları etkileyen hareketlerden doğan, olayları zaman ve yer göstererek anlatan, bu olaylar arasındaki ilişkileri, daha önceki ve sonraki olaylarla bağlantılarını, karşılıklı etkilenmeleri, her milletin kurduğu medeniyeti inceleyen bilim olarak tanımlanmaktadır. ${ }^{1}$ Tarih sadece toplumların nasıl bir işleyişi oldukları hakkında geniş esasları sunmak ile kalmaz aynı zamanda insanların hayatlarını sürdürme noktasında ihtiyaç duydukları topluma ilişkin işleyişle alakalı bir düşünce alt yapısı da sağlamaktadır. Tarih, ayrıca günümüzde, çevremizdeki değişmelere sebep olan faktörler de dahil olmak üzere toplumsal değişimin karmaşık süreçlerine dikkat çekmektedir. Geçmişi incelemenin insanları büyüleyen bir tarafı olduğu çok açıktır ve hangi alana özgü olursa olsun, o alanın tarihini öğrenmek okullardaki en önemli derslerden biri olarak kabul ve teşvik edilmelidir. ${ }^{2}$ Burada hemen "Geçmişini bilmeyen geleceğine yön veremez" özdeyişi akla gelmektedir. ${ }^{3}$ Aslında oldukça eski bir geçmişi olan Hemşirelik alanında "Hemşirelik Tarihi" nereden nereye gelindiği ve nereye gidilebileceği sorularına yanıt vermektedir. Hemşirelik Tarihi anlatımına yönelik verilecek eğitim ile hemşireliğin bugünkü statüsüne gelebilmesi için verilen mücadeleler yanında, bakım kavramında sosyo-kültürel ve teknolojik gelişmelerle yaşanan değişimler daha net anlaşılabilir hale gelecektir.

Tarih bilgisi anlatısal olarak nesilden nesile aktarılabildiği gibi yazılı metinlerle kayıt altına alınarak da aktarılmaktadır. Yazılı aktarımlar, yani literatür eğitim kurumlarında yararlanılan ana kaynaklardır. Türkiye'de hemşirelik tarihine ilişkin ana değerlendirme olarak, Selva Erhan tarafından yazılan ve ilk baskısı 1978 yılında yapılmış olan " Hemşirelik Tarihi” kitabı dışında konuya özgü bir kitap olmaması sorunu dile getirilebilir. Bu kitap günümüzde de güncellenmiş hali ile ders kitabı olarak kaynaklar arasında yer almaktadır. ${ }^{4}$

Ülkemizde XXI. yüzyıla kadar batı söylemlerine dayanan bir hemşirelik tarihi bilgisinin öğrencilere aktarılması söz konusu iken, bu tarihten sonra Tıp Tarihi ve Etik alanından doktora eğitimi almış olan yerli akademisyenlerin konuya eğilmeleri ile yerli literatür oluşmaya başlamıştır. ${ }^{5}$ Böylece Hemşirelik Tarihi derslerinde yerel tarihte ele alınır olmuştur.

Hemşirelik tarihine ilişkin yerel anlatımlarda genel geçer bir yaklaşım olarak hemşirelik eğitimindeki gelişme ve değişimler öncelikli olarak ele alınmaktadır. Kanımca bu yaklaşım, lisans düzeyinde eğitimin başlaması ile ulusal hemşirelik tarihimizin yazıı kayıtlarının sistematik bir şekilde tutulmasıyla bağdaştırılabilir. Bu bağlamda lisans düzeyinde hemşirelik eğitimi veren kurumların var oluş sürecine değinmek yerinde olacaktır. Türkiye ve Avrupa'da lisans düzeyinde eğitim veren ilk hemşirelik okulu olarak 1955 yılında açılan Ege Üniversitesi Hemşirelik Yüksekokulu (HYO) ile hemşirelikte lisans programları başlamıştır. ${ }^{6,7}$ Kronolojik olarak ikinci yüksekokul Hacettepe Üniversitesi'nde açılmıştır. Ardından 1961 yılında, İstanbul Florence Nightingale HYO açılımıştır. Sağlık Bakanlığı'na bağlı olarak kurulan bu yüksek okulun açıışında, dönemin Sağlık Bakanlığı müsteşarı ve sağlıkta sosyalizasyonun mimarı olan Dr. Nusret Fişek önemli destekte bulunmuştur. ${ }^{7-9}$ Atatürk Üniversitesi Hemşirelik Yüksekokulu 1982 yılında açılmış ve okul 2016 yılında Hemşirelik Fakültesine dönüşmüştür. Aynı yıl Cumhuriyet Üniversitesinde açılan Hemşirelik Yüksekokulu 2008'de Sağlık Bilimleri Fakültesine (SBF) dönüştürülmüştür. Atatürk Üniversitesi Hemşirelik Yüksekokulundan sonra 1985 yılında Gülhane Askeri Tıp Akademisi Hemşirelik Yüksekokulu subay hemşire ihtiyacını karşılamak üzere kurulmuştur. ${ }^{4,8}$ Daha sonra 1994 yılında Dokuz Eylül Üniversitesi Hemşirelik Yüksekokulu açılmıştır ve 2011'de Hemşirelik Fakültesine dönüştürülmüştür. İstanbul Üniversitesi Florence Nightingale Hemşirelik Fakültesi'nden sonra Türkiye'nin ikinci hemşirelik fakültesidir. ${ }^{8}$ Bu okullara ek olarak Marmara ve Gazi Üniversitelerinde birer Hemşirelik Yüksekokulu açılmıştır. Bakanlar Kurulunun 1996 yıındaki kararıyla, 79 Sağlık Yüksek Okulu açılması kararlaştırılmıştır. ${ }^{4,9,10}$ Illk kez Hacettepe Üniversitesinde 
hemşirelikte yüksek lisans (1968) ve doktora (1972) programlarına lisansüstü öğrenci alımıyla başlayan lisansüstü eğitim sekiz anabilim dalında yürütülmektedir. ${ }^{8}$

Ülkemizde 2019 yılı itibariyle 127 üniversitede 145 Hemşirelik Bölümünde aktif olarak hemşirelik lisans eğitimi verilmektedir. Biri vakıf üniversitesi olmak üzere 15 Hemşirelik Fakültesi, 94 Sağlık Bilimleri Fakültesi Hemşirelik Bölümü ve 34 Sağıık Yüksekokulu/ Sağlık Bilimleri Yüksekokulu ve üç Hemşirelik Yüksekokulu lisans düzeyinde hemşire eğitimi vermektedir. ${ }^{11}$ Bu veriler 2018 yılı verileri ile karşılaştırıldığında hemşirelik lisans programlarında hızlı bir değişim olduğu gözlenebilmektedir. YÖK tarafından 2017 yılında yapılan 'Hemşirelik Lisans Eğitimi Çalıştayı'nda da bu hızla program açılmasına yönelik çekinceler dile getirilmiş, ancak takip eden iki yılda bölüm sayıları değişmeye devam etmiştir. ${ }^{12} 2018$ yılında 44 olan Sağlık Yüksek Okulu sayısı 2019 yılında, on okulun fakülteye dönüştürülmesiyle 34'e düşerken, 83 adet olan Sağlık Bilimleri Fakültesi 94 'e ulaşmışır. ${ }^{11}$ Hemşirelik eğitimi veren fakülte ve yüksekokul sayısının bu kadar hızı artışı eğitim ve öğretimde sorunları da beraberinde getirmektedir. Bu sorunlardan biri Hemşirelik Tarihi dersini yakından ilgilendirmektedir. Öğretim elemanlarının artan ders yükü nedeniyle, uygulamalı dersler dışında kalan mesleki derslerden biri olan Hemşirelik Tarihi dersinin "üvey evlat" muamelesine maruz kalabildiğini söylemek olanaklıdır.

Hemşirelik lisans eğitimi veren kurumlarda Hemşirelik Tarihi eğitimi ya öznel bir ders olarak ya da başka derslerin içinde konu bazında verilmektedir. Günümüzde hemşirelik mesleğine ilginin artması sonucu öğrenci sayısındaki dramatik artışın hemşirelik felsefesinin öğrenci tarafından benimsenmesinde sorunlar ortaya çıkardığı kanaatindeyim. XX. yüzyılın hemşirelik eğitim programlarında kadın cinsiyetine özgü olarak özgeciliği benimseyerek yetişen hemşire figürü, yerini XXI. yüzyılda erkek üyelerin mesleğe katılması ve y kuşağının özellikleri nedeniyle bireyselliğe ve özerkliğe önem veren hemşire figürüne bırakmaktadır. Bu değişim ne yazık ki beraberinde hemşireliğin tarihsel gelişim ve değişime ilginin azalmasına neden olmuştur. Her ne kadar XXI. yüzyılda bilişim sistemleri sayesinde hemşirelik tarihine ilişkin bilgi birikimine ulaşmak daha kolay olsa da Türkiye'de hemşirelik tarihi açısından önemli sorunlardan birisi hemşirelerin kendi tarihsel geçmişlerine uzak kalmalarıdır. ${ }^{5}$ Hemşirelik tarihine ilişkin batı söylemli tarihi bilgilerin yanında kendi hemşirelik tarihimizi ortaya koymak ve mesleki bilinç geliştirmek önem arz etmektedir. Tarihsel bilinç ve mesleki aidiyet açısından ortak bir müfredat oluşturma gereksinimine duyulan ihtiyacın ortaya çıkmasıyla birlikte 2018 yılında Ege Üniversitesi Hemşirelik Fakültesinin ev sahipliğinde, hemşirelik tarihi eğitimi açısından büyük bir önem taşıyan "Hemşirelik Tarihi Öğretimi Çalıştayı" yapılmış ve konu ayrıntılı olarak ele alınmıştır. Çalıştay sonuç raporunda hemşirelik tarihi eğitimine hak ettiği önemin verilmesinde hem fikir olunmuştur. ${ }^{13}$

\section{Amaç}

Bu çalışmada amaç Türkiye’de Hemşirelik Tarihi lisans öğretiminin durumunu belirlemektir.

\section{Yöntem}

Tanımlayıcı olan çalışmada 10 Eylül 2018 tarihinde Yükseköğretim Kurumu istatistiklerinden yararlanarak aktif olarak Hemşirelik Lisans eğitimi veren Üniversiteler belirlenmiştir. 10-15 Eylül 2018 tarihleri arasında her üniversitenin bünyesindeki hemşirelik lisans programının internet sayfasından Hemşirelik Tarihi Dersine ilişkin bilgiler toplanmıştır. Ders adı, saati, yarıyılı, ders içeriği, dersi veren öğretim elemanı ve öğretim elemanın branşı ana değerlendirme konularını oluşturmuştur. Tüm kurumların internet adresleri üzerinden mevcut sayfaları ve var olanlarda ders içerikleri incelenmiştir. Verilerin analizinde sayı (n) ve yüzde (\%) kullanılmıştır. 


\section{Bulgular ve Tartışma}

Türkiye'de 2018 Eylül dönemi itibariyle aktif olarak eğitim veren ve program açık olmakla birlikte öğrenci almayan (pasif olan) toplam 142 hemşirelik bölümü olduğu saptanmıştır (Tablo 1).

Tablo1. Türkiye'de lisans düzeyi eğitim veren Hemşirelik bölümleri

\begin{tabular}{|c|c|c|c|c|c|c|}
\hline \multirow[t]{2}{*}{ Kurumlar } & \multicolumn{2}{|c|}{ Devlet } & \multicolumn{2}{|c|}{ Vakıf } & \multicolumn{2}{|c|}{ Toplam } \\
\hline & Sayı & $\%$ & Sayı & $\%$ & Sayı & $\%$ \\
\hline Hemşirelik Fakültesi & 14 & 13,5 & 1 & 2,6 & 15 & 10,6 \\
\hline Sağlık Bilimleri Fakültesi & 55 & 52,9 & 28 & 73,7 & 83 & 58,5 \\
\hline $\begin{array}{l}\text { Sağlık Yüksekokulu } \\
\text { Sağlık Bilimleri Yüksekokulu } \\
\text { Hemşirelik Yüksekokulu }\end{array}$ & 35 & 33,6 & 9 & 23,7 & 44 & 30,9 \\
\hline Toplam & 104 & 73,23 & 38 & 26,77 & 142 & 100 \\
\hline
\end{tabular}

Hemşirelik eğitimi veren 142 kurumun \%41,54 ünde içeriğinde hemşirelik tarihi olan dersler ders kataloglarında yer almaktadır. Ders programlarında hemşirelik tarihine ilişkin ders olan lisans programlarının ( $n=59)$ dağılımı incelendiğinde, \%88,14'ünün devlet, \% 11,86'sının vakıf üniversitelerine bağıı olduğu saptanmıştır. Hemşirelik tarihi içerikli ders verilen devlet üniversitelerine bağlı olan hemşirelik lisans programlarının ( $n=52$ ) \%61,53'ü Sağlık Bilimleri Fakülteleri iken, \% 7,7'si Hemşirelik Fakülteleri olarak saptanmıştır. Vakıf üniversitelerine bağlı olanlardan $(n=38)$ ise $\% 11,86$ 'sında hemşirelik tarihi içerikli derslerin ders kataloğunda yer aldığı saptanmıştır. Hemşirelik Tarihine ilişkin lisans eğitiminin verildiği saptanmıştır (Tablo 2). Hemşirelik lisans eğitimi veren 38 vakıf üniversitesinin yalnızca yedisinde hemşirelik tarihine ilişkin ders olması, meslek tarihine özgü eğitimin önemsenmediği değerlendirmesi yapılabileceği gibi eğitim kadrosunda bu dersi verebilecek öğretim elemanı olmaması durumu nedeniyle de göz ardı edildiği düşünülebilir. Aynı yorum nispeten daha yüksek bir orana sahip olan Devlet üniversitelerine ait lisans programları için de söylenebilir. Hemşirelik Tarihi konusunda Lisansüstü eğitim olanağının olmaması, dersi anlatacak öğretim elemanı bulmakta güçlük çekilmesine neden olmuş olabilir. Ek olarak tarih derslerine ilişkin kaynak sıkıntısı nedeniyle öğretim elemanları bu dersi üstlenmek istememiş olabilirler. Alışılagelmiş ve makalenin ilerleyen satırlarında görüleceği üzere Hemşirelik Esasları ve Hemşirelikte Yönetim Anabilim Dalında görev alan öğretim elemanları ağırlıklı olmakla birlikte neredeyse hemşirelik alanında her anabilim dalından öğretim elemanları hemşirelik tarihi dersinin sorumluluğunu almıştır.

Tablo 2. Türkiye'de Lisans Düzeyi Hemşirelik Tarihi Dersi Olan Bölümler (N=142)

\begin{tabular}{|c|c|c|c|c|c|c|}
\hline \multirow[t]{2}{*}{ Kurumlar } & \multicolumn{2}{|c|}{ Ders olan Devlet Ü. (n=104) } & \multicolumn{2}{|c|}{ Ders olan Vakıf Ü. (n=38) } & \multicolumn{2}{|c|}{ Toplam } \\
\hline & Sayı & $\% *$ & Sayı & $\% *$ & Sayı & $\% *$ \\
\hline Hemşirelik Fakültesi & 4 & 7,7 & - & - & 4 & 6,78 \\
\hline Sağlık Bilimleri Fakültesi & 32 & 61,53 & 5 & 71,42 & 37 & 62,71 \\
\hline Sağlık Yüksekokulu & 16 & 30,77 & 2 & 28,58 & 18 & 30,51 \\
\hline \multicolumn{7}{|c|}{ Sağlık Bilimleri Yüksekokulu } \\
\hline \multicolumn{7}{|l|}{ Hemşirelik Yüksekokulu } \\
\hline Toplam** & 52 & 88,14 & 7 & 11,86 & 59 & 100 \\
\hline
\end{tabular}

*Sütun \%,** Satır \% kullanılmıştır.

Lisans düzeyinde hemşirelik eğitimi veren ve müfredatında ya da içeriğinde hemşirelik tarihi olan dersler; "Hemşirelik Tarihi", "Hemşirelik Tarihi ve Deontoloji", "Hemşirelik Tarihi ve Etik", "Hemşirelik Tarihi, Yasaları ve Etik", "Meslek Tarihi ve Deontoloji", "Hemşirelik Tarihi ve Kavramsal Çerçevesi", "Hemşirelik Tarihi ve Felsefesi", "Hemşirelik Deontolojisi ve Yasaları", "Hemşirelik Tarihi Kavramı ve İlkeleri" adları ile kurumların web sayfalarında yer almaktadır. ${ }^{14-20}$ Farklılıkların yalnızca dersin adıyla sınırlı kalmayıp, yarıyıl, ders saati ve içerikte de olduğu görülmektedir. Şekil 1'de bu konuya özgü birkaç örnek yer almaktadır. ${ }^{14,21-26}$ 


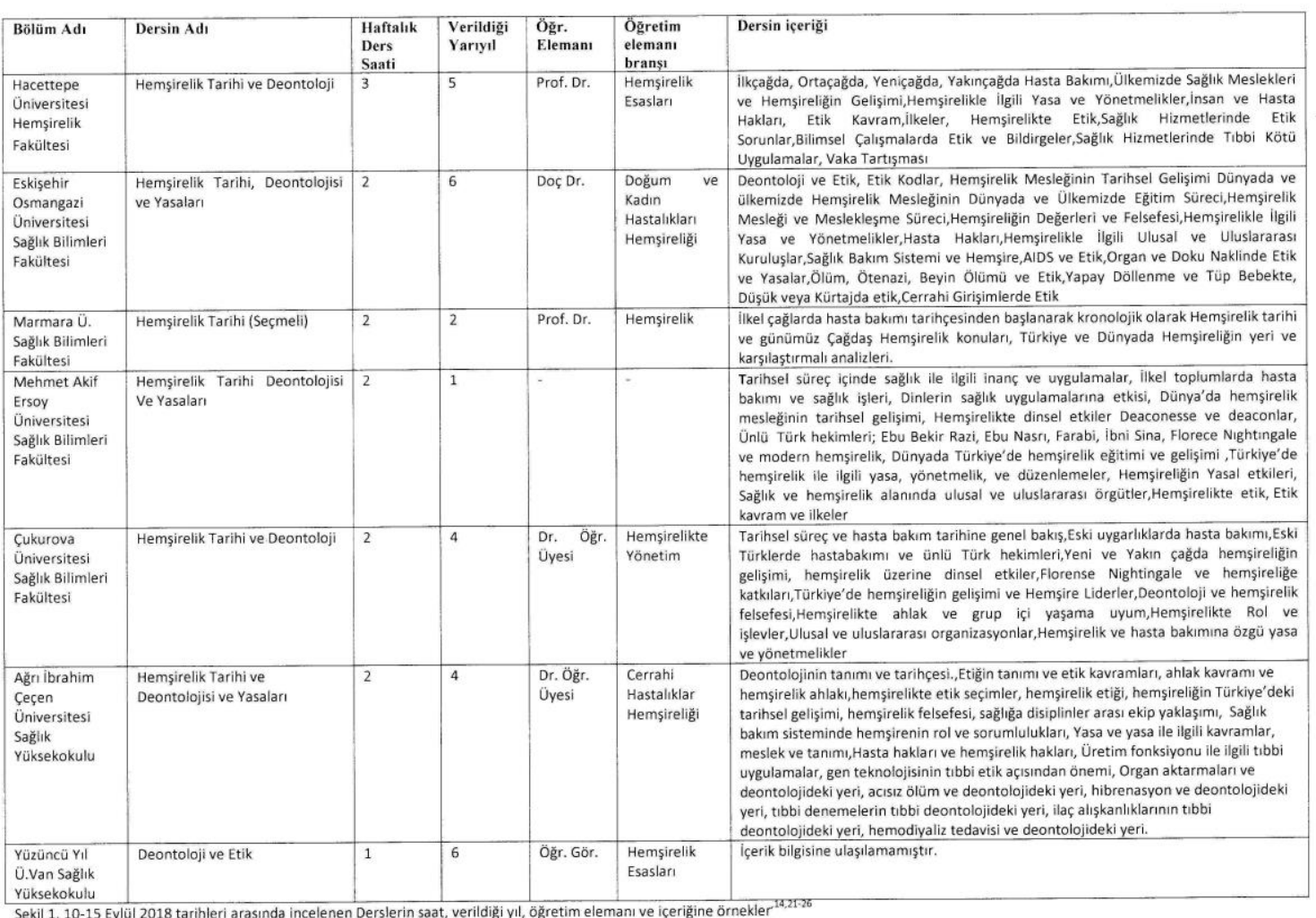

Derslerin ad ve içeriklerinin farklı olması kanımca, Hemşirelik Tarihi dersinin öğrenim kazanımlarının neler olacağı ve kullanılacak öğretim yöntemleri konusunda karmaşa ortaya çıkarmaktadır. İçeriği yalnızca tarih olan, haftada iki saatlik bir derste, hasta bakım tarihine ilişkin dünya genelinde ve ülke özelinde bilgiler rahatıkla öğrenciye aktarılabilir. Bu aktarım, konuya ve beraberinde tarih anlatım yöntemlerine hakim öğretim elemanları için kolay bir iştir. Tarih anlatımına yabancı öğretim elemanları için çok zor gelebilir. Öğrenci açısından da yalnızca düz bir anlatımla aktarılan tarih bilgisi, unutulmak üzere kurgulanmış ve geçer not alabilecek kadar üzerinde durulması gereken bir ezber dersi olarak görülebilir.

Oysa bir bilim dalı olarak tarih, dün-bugün-gelecek arasında ilişki kurmayı amaçlamakta ve doğru bilinç geliştirmeyi sağlamaktadır. ${ }^{27}$ Hemşirelik Tarihi dersi de hemşirelik öğrencilerinin hasta bakımı tarihi ile mesleki gelişim ve değişimleri öğrendikleri, dün-bugün ve gelecek arasında ilişki kurdukları bir derstir. Tarih dersleri nasıl öğrencilerin analitik ve eleştirel düşünme becerileri gibi zihinsel becerilerini geliştiriyorsa, Hemşirelik Tarihi dersi de bu becerileri geliştirmektedir. Yıldız'a göre; hiç kimse bir işi, o işin geçmişi ile ilgili ayrıntılı bilgi toplamadan yapamaz. ${ }^{27}$ Hemşirelik Tarihi öğretiminde öğrenciye, geçmiş hakkında bilmesi gereken oranda ve çerçevede, geleneğe dayalı bilgiler vermek; hemşireliğin uzun bir yol kat ederek bugüne geldiği ve yoluna devam edeceğini hissettirmek; mesleki anlamda öğrendiklerine temel oluşturan bilgileri aktararak pekiştirmesine yardımcı olmak amaçlanmaktadır. ${ }^{14} \mathrm{Bu}$ amaca ulaşmak için tarih bilgisinin aktarımında kullanılan yaklaşım ve yöntemler hemşirelik tarihi aktarımında da kullanılabilir. Demircioğlu, tarih öğretiminde geleneksel ve çağdaş olarak iki yaklaşıma değinmektedir. ${ }^{28}$ Geleneksel yaklaşımı hemşireliğe uyarlarsak; öğrencilere geçmişin bilgisi öğretilerek mesleğin tarihini, mesleğe katkı sağlayan meslektaşlarını, değerlerini, kültürünü tanıyan ve benimseyen iyi meslektaşlar yetiştirilmesi hedeflenmektedir. İkinci yaklaşım ise öğrencilere bilimsel bakış açısı veren, üst düzey düşünme becerileri 
kazandıran, öğrencilerin tarihçinin kaynaklarını kullanarak tarihçi gibi bilgileri keşfetmelerini sağlayan yaklaşımdır. ${ }^{29}$ Bu yaklaşımla bilimsel ve analitik düşünebilen hemşirelerin yetiştirilmesine katkı sağlanır.

Hendry'e göre tarih öğretimindeki ilkeler; bilginin yorumlanması ve aktarımı, öğrencinin kendi bilgi ve yaşantılarına göre farklı anlamlar türetmesi, öğrenen ile öğretenin bilgi dünyaları arasındaki etkileşim ve bilginin değişime açık olduğudur. ${ }^{30}$ Demircioğlu'na göre, geçmişten dersler çıkarmamızı sağlayan tarih, değerleri insanlara ulaştırmada önemli bir araçtır. ${ }^{28}$ Tarih dersleri ile öğrencilere; merak etme, özgürce düşünebilme ve dile getirme, bilimsel temele dayalı tartışmalar yapabilme, grup çalışması yapabilme, araştırma yapabilme ve çok yönlü düşünebilme, hoşgörülü olma, önyargı ve genellemelerden uzak değerlendirme yapabilme becerileri kazandırılabilir. ${ }^{29}$ Bütün bu beceriler eleştirel ve çok yönlü düşünebilen bireylerin yetiştirilmesinde önemlidir. ${ }^{31}$ Tarih derslerinde diğer derslerde olduğu gibi seçilen konular, araç gereçler, kullanılan yöntemler dersin hedefine ulaşmasında etkilidir. Tarih eğitiminde hikâyeler, biyografiler, efsaneler, destanlar, çevre ve müze gezileri gibi yaklaşımlar, değer aktarımı için elverişli ortamlar yaratırlar. ${ }^{32}$ Deneyimlerime dayanarak derste öğretim yöntemlerinden anlatım, görsel materyal kullanımı, soru cevap, beyin fırtınası, rol play, film izletme, müze ve çevre gezileri öğrenmeyi kolaylaştırmakta ve derse olan ilgiyi aktif tutmaktadır.

Hemşirelik Tarihi dersi öğrenim kazanımları arasında öğrencinin bireysel gelişimine katkı sağlayan geçmiş ve gelecek arasında bağ kurabilme, empatik düşünmebilme, hasta bakımında günümüze kadar uygulanmış yöntem ve sistemleri anlayabilme ve dolayısıyla mesleki değerleri anlayıp benimseyebilme yer almaktadır. ${ }^{14}$ Bu nedenle aslında tüm hemşirelik lisans programlarında yer alması gerekmektedir. Ancak ele alınması gereken önemli sorunlardan biri; yukarıda kısaca dile getirilen tarih bilgisinin öğrenciye aktarımının sağlıklı olabilmesi için tarih anlatımına ilişkin donanıma sahip öğretim elemanı bulunmamasıdır. Bu nedenle Hemşirelik Tarihi Anabilim Dalları kurulmalı ve bu alanda yetkin öğretim elemanlarının yetişmesi sağlanmalıdır.

Araştırma kapsamında ders içeriklerinin incelemesi sonrasında Deontolojinin eklendiği derslerde yapılan değerlendirme sonucunda, mevzuat ağırlıklı konuların ele alınmakta olduğu söylenebilir. Mevzuat bilgileri, öğrencide farkındalık yaratması ve zorunluluk halinde başvuracağı yasa ve yönetmeliklerin varlığını öğrenmesi açısından önemlidir. Ayrıca hak ve sorumluluklar konusunda bilinçli çalışanlar yetişmesini sağlaması açısından yasa ve deontoloji içerikli derslerin olmasının da önemli olduğu düşüncesindeyim. Ancak tarih ve yasaların bir arada işlenmesi zaman açısından sıkıntı yaratmaktadır. Derslerin konularına ilişkin tasarım, dersin sorumlu öğretim elemanına kaldığı için kendi ilgi alanına ya da daha rahat aktarabileceği konulara ağırlık verilmesi sakıncasını beraberinde getirebildiğini söylemek olanaklıdır. Bu durumda öğretim elemanının ilgi duymadığı ya da anlatmakta zorlandığı konuların yeterince önemsenmemesi tehlikesi ortaya çıkmaktadır. Etik dersi ele alınacak olursa, kavramsal çerçeve ve felsefe konuları bir derse ek yapılarak anlatılamayacak kadar kapsamlı olduğu yadsınamaz bir gerçektir. Etik konuları Hemşirelik Tarihi dersine eklenebilecek içerikte bir ders konusu olarak görülmemeli, ayrı bir ders olarak eğitim öğretim müfredatında yer almalıdır. Böylece öğrencinin bu alanda daha donanımlı yetişmesini sağlanabilir. Hemşirelik Felsefesi ise özel ve mesleki yaşamda bireysel ve mesleki değerlerin gelişmesine katkı sağlayan ayrı bir ders olarak müfredatta yer almalıdır.

Tüm bu derslerin her biri tek başına hemşirelik eğitiminin temel taşlarıdır ve bunları bir araya getirip kısaca söz edilemeyecek kadar önemlidir. Yukarıda söz edilen tüm derslerin ayrıntılı olarak öğrenciye verilmesi mesleki yaşantılarında mesleğin toplumsal kabul edilirliğini ve güvenilirliğini etkileyecek hemşireler yetişmesini sağlayacağı görüşünde olduğumu belirtmek yerinde olacaktır. 
Hemşirelik Tarihine ilişkin lisans eğitiminin standart hale gelebilmesi Hemşirelik Tarihi ve Etik alanında lisansüstü eğitim ve bu alanın doçentlik alanı olarak tanınması ile mümkün olabilecektir. Hemşirelik tarihi eğitiminde atılması gereken en önemli adım daha önce de değinildiği gibi hemşirelik tarihini bir anabilim dalı olarak kabul etmektir. Mustafa Kemal Atatürk'e göre "tarih yazmak tarih yapmak kadar mühimdir, yazan yapana sadık kalmazsa değişmeyen hakikat, insanlığı şaşırtacak bir mahiyet alır". ${ }^{33}$ Atatürk bu ifadesinde olanların tüm gerçekliğiyle yorum katmadan aktarılması gerektiğini vurgulamaktadır. Hemşirelik tarihi açısından bu aktarım tarih metodolojisine ve hemşireliğe hakim yazarlarca yapılırsa daha doğru ve öznel olacaktır. Bu amaç ile Türkiye'de ilk kez 2014 yılında Çukurova Üniversitesi Sağlık Bilimleri Enstitüsü Hemşirelik Anabilim Dalı Hemşirelik Tezli Yüksek Lisans programı içinde «Hemşirelik Tarihi ve Etik» Yüksek Lisans programı açılmış ve dersler belirlenmiştir (Tablo 3). Ancak, 'doçentlik' alanı olmadığı için hemşirelik camiasında pek destek görmemiştir. Yurt dışında "Hemşirelik Tarihi" anabilim dalı olarak bulunmaktadır. Ülkemizde 2019 yılında Sakarya Üniversitesi Sağlık Bilimleri Fakültesi Hemşirelik Bölümünde Hemşirelik Tarihi ve Etik Anabilim Dalı kurulmuştur. ${ }^{34}$

Tablo 3. Çukurova Üniversitesi Sağıık Bilimleri Enstitüsü Hemşirelik Yüksek Lisans Programı Hemşirelik Tarihi ve Etik Yüksek Lisansı Seçmeli Dersleri

\begin{tabular}{|c|c|c|c|c|}
\hline Ders Adı & Akts & Teorik & Uygulama & Kredi \\
\hline HEM541 -Hemşireliğin Tarihsel Gelişimi & 3 & 2 & - & 2 \\
\hline HEM549- Tıp Tarihi ve Tıp Etiği Temel Bilgileri & 4 & 3 & - & 2 \\
\hline HEM555-Hemşirelik Tarihi ve Etiği Semineri1 & 2 & 1 & - & 1 \\
\hline HEM551- Türkiyede Hemşireliğin Gelişimi ve Bilimselleşme Süreci & 3 & 2 & - & 2 \\
\hline HEM552- Sağlık Politikaları ve Hemşirelik & 3 & 2 & - & 2 \\
\hline HEM550- Bilim Tarihi ve Etiği & 3 & 2 & - & 2 \\
\hline HEM569- Hemşirelikte Etik & 6 & 2 & 4 & 4 \\
\hline HEM578- Hemşirelikte Malpraktis & 3 & 2 & - & 2 \\
\hline HEM553- Hemşirelikte Araştırma ve Yayın Etiği & 3 & 2 & - & 2 \\
\hline HEM554- Hemşirelik Mevzuatı ve Etik Kodlar & 3 & 2 & - & 2 \\
\hline HEM556-Hemşirelik Tarihi ve Etiği Semineri2 & 2 & 1 & - & 1 \\
\hline
\end{tabular}

\section{Sonuç ve Öneriler}

Sonuç olarak; Hemşirelik Tarihine yönelik derslerin adı, dersin verildiği yıl/yarıyıl, saati, dersi veren öğretim elemanının branşı ve en önemlisi dersin içeriği konusunda ne yazık ki bir standart bulunmamaktadır. Öğretim elemanının ilgi ve bilgisine göre değişiklikler yaşanmaktadır. Hemşirelik eğitimi veren 142 kurumun \%41,54 ünde içeriğinde hemşirelik tarihi olan dersler ders kataloglarında yer almaktadır Hemşirelik Fakültelerinin çoğunda bu alana özgü derse rastlanmamakla birlikte hemşirelik tarihi ve ilişkili derslerin ağırlıklı olarak Sağlık Bilimleri Fakültelerinin müfredatında bulunduğunu söylemek olanaklıdır.

Hemşirelik Tarihine yönelik derslerin adı, dersin verildiği yıl/yarıyıl, saati, dersi veren öğretim elemanının branşı ve dersin içeriği konusunda bir standart sağlanmalıdır. Tüm fakülte ve yüksekokullarda hasta bakım tarihi zorunlu ders olarak anlatılmalıdır. Alana özgü Tıbbi Deontoloji, Hemşirelik Felsefesi, Sağlık Mevzuatı, Hemşirelik Mevzuatı, Hasta Hakları ve Malpraktis gibi seçmeli derslerle öğrencinin entelektüel birikimi desteklenmelidir. Tıbbi Deontoloji ve Tıbbi Etik ayrı dersler olarak verilmelidir. Hemşirelik Tarihi ve Etik alanında Lisans üstü eğitim için Anabilim dallarının yaygınlaşması, bu alanda akademisyenler yetiştirilmesine hız verilmesi ve 2019 da YÖK tarafından kabul gören Hemşirelik Tarihi ve Etik anabilim dalının doçentlik alanı olarak kabul edilmesi gerekmektedir. Bu kabulü hızlandırmak adına, öncelikli olarak akademik hemşirelik camiasının bu alana destek vermesini sağlamak üzere bu konuya ilişkin çalıştaylar düzenlenmesi ve ortak görüş bildirilmesi süreci hızlandırmak açısından önerilmektedir. 


\section{Bilgi}

Bu çalışma 19 Eylül 2018'de Ege Üniversitesi Hemşirelik Fakültesi tarafından düzenlenmiş olan 1. Uluslararası 3.Ulusal Hemşirelik Tarihi Kongresinin "Hemşirelik Tarihi Öğretimi " Çalıştayı'nda sunulmuştur.

\section{Kaynaklar}

1. Türk Dil Kurumu Sözlüğü (TDK). [Erişim Tarihi: 01.08.2019]. Erişim Adresi: http://sozluk.gov.tr/

2. Stearns PN, Dinç E. Neden Tarih Öğreniyoruz. Uşak Üniversitesi Sosyal Bilimler Dergisi 2009;3:118-127

3. Gümüşoğlu HD. Mansur Baba Haziresi'ndeki Son Osmanlıca Bektaşi Mezar Taşları. Türk Kültürü ve Hacıbektaş Veli Araştırma Dergisi 2018; 35:9-41.

4. Erhan Şentürk S. Hemşirelik Tarihi. İstanbul: Nobel Tıp Kitabevleri; 2011. ss107-138.

5.Torun S. Kırım Savaşında Hasta Bakımı ve Hemşirelik. Ankara: Akademisyen Yayınevi; 2014.

6. Ergöl Ş. Türkiye'de Yükseköğretimde Hemşirelik Eğitimi. Yükseköğretim ve Bilim Dergisi 2011;1(3):152-155.

7. Akdur R, Aydın E. Tıbbi Etik ve Meslek Tarihi. Ankara: Songür Yayıncılık; 2003. ss89-92.

8. Yürügen B. Türkiye'de Hemşirelik ve Hemşirelik Eğitimi Tarihi, Erişim Tarihi: 04.07.2019. Erişim Adresi: http://www.hemsireyiz.biz/blogs/makaleler/archive/2007/01/04/Turkiyedehemsirelikvehemsirelikegitimi.

9. Kıran B, Akçiçek E, Taşkıran EG. Geçmişten Günümüze Türkiyede Hemşirelik Eğitimi ve Hemşirelikte İnsan Gücü Planlaması. 1.Ulusal Hemşirelik Tarihi Kongresi Özet Kitabı. İzmir: Meta basım yayıncılık; 2016. ss434-436.

10. Ökdem Ş, Abbasoğlu A, Doğan N. Hemşirelik tarihi, eğitimi ve gelişimi. Ankara Üniversitesi Dikimevi Sağlık Yüksekolu Yıllı̆̆ı 2000; 1(1): 5-11.

11. Hemşirelik Lisans Programları, https://istatistik.yok.gov.tr/, erişim tarihi: 02.07.2019.

12. Hemşirelik Lisans Eğitimi Çalıştayı sonuç raporu, Yüksek Öğretim Kurulu (YÖK), 23.11.2017 Ankara. Erişim Adresi:https://www.yok.gov.tr/Documents/Yayinlar/Yayinlarimiz/ Hemsirelik_Lisans_Egitimi_Calistayi_Sonuc_Raporu.pdf

13. Hemşirelik Tarihi Öğretimi Çalıştayı Sonuç Raporu. 1.Uluslarası 3. Ulusal Hemşirelik Tarihi Kongresi, Ege Üniversitesi, İzmir, 19-21 Eylül 2018.

14. Çukurova Üniversitesi Sağlık Bilimleri Fakültesi Hemşirelik Bölümü Ders Kataloğu. [Erişim Tarihi:10.06.2018]. Erişim Adresi: https://eobs.cu.edu.tr/ProgDersPlan_tr.aspx? ProgID=204

15. Ankara Üniversitesi Açık Ders Malzemeleri. [Erişim Tarihi: 10.06.2018]. Erişim Adresi: https://acikders.ankara.edu.tr/course/view.php?id=643

16. Karamanoğlu Mehmetbey Üniversitesi Sağlık Yüksekokulu Hemşirelik Bölümü Ders Müfredatı. [Erişim Tarihi: 10.06.2018]. Erişim Adresi: http://dosya.kmu.edu.tr/ogris/userfiles/file/ogris/dersicerik/dersiceriksyo.pdf

17. Selçuk Üniversitesi Akşehir Kadir Yallagöz Sağlık Yüksekokulu Hemşirelik Ders İçeriği. [Erişim Tarihi: 10.06.2018]. Erişim Adresi: https://www.selcuk.edu.tr/aksehir_kadir_yallagoz_saglik_yo/hemsirelik/bolum_dersleri/7703302/tr

18. Sağlık Bilimleri Üniversitesi Hemşirelik Programı Ders Müfredatı. [ErişimTarihi:10.06.2018]. Erişim Adresi: http://hemsirelik.sbu.edu.tr/EgitimBilgileri/Hemsirelik ProgramiDersMufredati

19. Arel Üniversitesi Sağlık Bilimleri Yüksekokulu Hemşirelik Bölümü Ders İçerikleri. [Erişim Tarihi: 10.06.2018], Erişim adresi: https://www.arel.edu.tr/saglik-bilimleri-yuksekokulu/hemsirelik-bolumu/ders-icerikleri

20. Muğla Sıtkı Koçman Üniversitesi Fethiye Sağlık Yüksekokulu Hemşirelik Ders Kataloğu. [Erişim Tarihi: 10.06.2018]. Erişim adresi: http://ects.mu.edu.tr/tr/program/108

21. Hacettepe Üniversitesi Hemşirelik Fakültesi, Ders Bilgi Paketi. [ErişimTarihi:10.06.2018]. Erişim Adresi: http://akts.hacettepe.edu.tr/program_detay.php?birim_ref=AKDBRM

22. Eskişehir OsmanGazi Üniversitesi Sağlık Bilimleri Fakültesi Hemşirelik Bölümü Ders Bilgi Paketi. [Erişim Tarihi:10.06.2018]. Erişim Adresi: https://sbf.ogu.edu.tr/Sayfa/Index/55/hemsirelik-fakulte-ders-icerikleri

23. Marmara Üniversitesi Sağlık Bilimleri Fakültesi Hemşirelik Bölümü Ders Kataloğu [Erişim Tarihi:10.06.2018]. Erişim Adresi: https://sbf.marmara.edu.tr/ogrenci/ders-programlari/

24. Mehmet Akif Ersoy Üniversitesi Sağlık Bilimleri Fakültesi Hemşirelik Bölümü Ders Bilgi Paketi, [Erişim Tarihi:10.06.2018]. Erişim Adresi: https://obs.mehmetakif.edu.tr/oibs/bologna/start.aspx?gkm=01893.

25. Ağrı İbrahim çeçen Üniversitesi Sağlık Yüksekokulu, Hemşirelik Bölümü Ders Bilgi Paketi, [ Erişim Tarihi:10.06.2018]. Erişim Adresi:https://obs.agri.edu.tr/oibs/bologna/start.aspx?gkm= 
26. Van Yüzüncü Yıl Üniversitesi Van Sağlık Yüksekokulu Hemşirelik Bölümü Ders Bilgi Paketi. [Erişim Tarihi:10.06.2018]. Erişim Adresi: https://obs.yyu.edu.tr/ogrenci/ebp/course.aspx?zs=1\&mod=1\&kultur=tr-

R\&program $=8661 \&$ did $=308062 \& \mathrm{mid}=963295 \& \mathrm{pmid}=19050$.

27. Yıldız Ö. Türkiye'de Tarih Öğretiminin Sorunları Ve Çağdaş Çözüm Önerileri Sosyal Bilimler Enstitüsü Dergisi. 2003; 1(15):181190.

28. Demircioğlu ïH. Tarih öğretiminde öğrenci merkezli yaklaşımlar. Ankara: Anı Yayıncılık. 2007.

29. Demircioğlu iH, Tokdemir MA. Değerlerin Oluşturulma Sürecinde Tarih Eğitimi: Amaç, İşlev ve İçerik. Değerler Eğitimi Dergisi. 2008; 6(15): 69-88.

30. Hendry G.Teaching With an Intranet, University of Birmingham, London.1996.

31. Philips R. History, citizenship and identidy. Teaching history 2003;36(2), 37- 41.

32. Ulusoy K. Tarih dersinde ahlaki değerlerin aktarımı, bir okuma parçası örneği. Milli Eğitim 2005; 168; 126-133.

33. Eroğlu H. Mustafa Kemal Atatürk'ün Tarih Anlayışı Ille İlgili Bazı Görüşler. Ankara Üniversitesi Türk İnkılâp Tarihi Enstitüsü Atatürk Yolu Dergisi 2002; (29-30): 75-85.

34. Düzce Üniversitesi Duyurular. [Erişim Tarihi: 01.08.2019]. Erişim Adresi: https://duzce.edu.tr/ 14977-duyurusu-ulkemizde-ilk-vetek-olan-hemsirelik-tarihi-ve-etik-ana-bilim-dali-universitemizde-acildi 